\title{
S Gene Mutants Occurrence Among Hepatitis B Carriers in Malaysia
}

\author{
Jeyanthi Suppiah ${ }^{1, *}$; Rozainanee Mohd Zain ${ }^{1}$; Norazlah Bahari ${ }^{2}$; Salbiah Haji Nawi ${ }^{3}$;Zainah \\ Saat ${ }^{1}$ \\ ${ }^{1}$ Virology Unit, Institute for Medical Research, Kuala Lumpur, Malaysia \\ ${ }^{2}$ Pathology Unit, Selayang Hospital, Selangor, Malaysia \\ 3 Microbiology Unit, Hospital Kuala Lumpur, Kuala Lumpur, Malaysia \\ *Corresponding Author: Jeyanthi Suppiah, Virology Unit, Institute for Medical Research, Kuala Lumpur, Malaysia. Tel: +603-26162674, E-mail: jeyanthi@imr.gov.my
}

Received: August 6, 2014; Revised: October 11, 2014; Accepted: November 22, 2014

\begin{abstract}
Background: The S gene region of the hepatitis B virus (HBV) codes for surface antigen ( $\mathrm{HBs} \mathrm{Ag}$ ) and is responsible for classification of HBV strains.

Objectives: The current study aimed to identify important mutations in the S gene in Hepatitis B virus (HBV) isolated from Malaysian HBV carriers.

Materials and Methods: Isolated HBV DNAs were subjected for PCR amplification and sequencing of HBV full genome.

Results: A total of $76 \mathrm{HBV}$ full genome and 17 partial genome sequences were obtained from the 93 sequenced sera samples Genotyping of the full genome sequences by HEPSEQ software revealed a distribution of $49.46 \%, 48.39 \%$ and $2.15 \%$ of genotypes C, B, and D, respectively; whereas phylogenetic and jumping profile Hidden Markov Model (jpHMM) analysis identified six (7.89\%) recombinant B/C strains. The distribution of sub-genotypes were B2 (78.79\%) and B3 (21.21\%) for genotype B, sub genotype D2 (100\%) for genotype D and sub genotype C1 (75.76\%), C2 (15.15\%), C3 (6.06\%) and C5 (3.13\%) for genotype C. Mutation analysis in the S gene demonstrated two significant mutations which were W182 stop codon and deletion at open reading frame (ORF) of pre-S1 with the frequency occurrence of 2.2\% (2/93) and 5.4\% (5/93), respectively. The two patients with W182 stop codon were both male, infected with HBV genotype $\mathrm{C}$ and one showed progression of liver disease to hepatocellular carcinoma (HCC).

Conclusions: Association with sex, genotype and clinical symptoms revealed that the pre-S1 ORF deletion occurred in $40 \%, 40 \%$,and $20 \%$ of genotypes B,C, and D respectively, and $80 \%$ of the female population, of which all but one were diagnosed with chronic hepatitis $\mathrm{B}$. Additionally, several mutations were found in the BCP region with the following incidence rate; C1653 T (8.6\%), A1752 G (10.8\%),1762 AGG-TGA 1764 (26.9\%), C1766T(2.2\%),T1768 A(10.8\%), C1858 T(64.5\%), G1896 A (25.8\%).
\end{abstract}

Keywords:Hepatitis B Virus; Codon; Carcinoma; Genotype

\section{Background}

The Hepatitis B virus (HBV) genome comprises a partially double stranded $3.2 \mathrm{~kb}$ DNA with four open-reading frames (ORF). These ORF's encode the polymerase gene ( $P$ gene), core antigen ( $C$ gene), large, medium and small surface antigen proteins ( $\mathrm{S}$ gene) and the $\mathrm{X}$ protein (X gene) (1). The full genome analysis of HBV revealed abundant information including identification of mutations reported worldwide in all the four open reading frames (2). Malaysia is a country of medium seroprevalence for the HBV surface antigen (HBsAg) in the general population (range 1.5-9.8\%) (3). Most carriers are infected prenatally owing to the high viral load in Malaysian women of child-bearing age (4). The S gene region of the hepatitis B virus is of particular interest, since it is responsible for the expression of surface antigens and classification of HBV strains. Initially, HBV strains were classified based on the immunological heterogenecity of HBsAg. Following the advances in molecular techniques, serotype-based classification was estab- lished based on the variants in the major hydrophilic region (MHR) (5). The presence of immune escape mutants in this region gives HBV variants a distinct survival advantage, permitting the mutant virus to escape from the immune system. This is worrisome in the context of public health, because these mutant viruses can reduce sensitivity of diagnostic assay by causing false negative result. Besides, it can result in failure of vaccination if not detected early.

\section{Objectives}

The current study aimed to identify the occurrence of $S$ gene mutants among Hepatitis B carriers in Malaysia.

\section{Materials and Methods}

\subsection{Ethics Statement}

The current study was ethically approved by Ethics and Medical Research Committee, Ministry of Health

Copyright ( 2014, Kowsar Corp. This is an open-access article distributed under the terms of the Creative Commons Attribution-NonCommercial 4.0 International License (http://creativecommons.org/licenses/by-nc/4.0/) which permits copy and redistribute the material just in noncommercial usages, provided the original work is properly cited. 
Malaysia (Reference number: NMRR-12-311-11789). The ethics committee did not deemthe patient consent necessary,since the samples used were retrospective and confirmed as Hepatitis B carriers by Selayang Hospital, Kuala Lumpur, Malaysia.

\subsection{Serum Samples}

A total of 93 retrospective blood serum samples of the confirmed Hepatitis B carriers were obtained in a volume of $2 \mathrm{~mL}$ from the Pathology Unit, Selayang Hospital, Kuala Lumpur, Malaysia. Hepatitis B carriers are defined as persons positive for Hepatitis B surface antigen (HBsAg) for more than six months. The samples were randomly collected regardless of age, race, sex, treatment, and symptoms for a period of three years (2012-2014). The demographic data of the patients participating in the study were summarized in Table 1.

\subsection{HBV DNA Extraction}

HBV DNA was extracted from sera samples using High Pure Viral Nucleic Acid Extraction Kit (Roche, USA) according to the manufacturer's instructions. The final elution contained $50 \mu \mathrm{L}$ of viral DNA and was stored at $-20^{\circ} \mathrm{C}$ for long term usage.

\subsection{HBV Full Genome Amplification}

The $3.215 \mathrm{~kb}$ length HBV full genome was amplified using 14 sets of the previously published oligonucleotides $(6,7)$. The primers published by Sugauchi et al. (6) were used to perform the nested PCR whereas amplification with primers published by Kahila Bar-Gal et al. (7) were done by direct PCR. All oligonucleotides used in the study are listed in Table 2. A fragment of $3.2 \mathrm{~kb}$ was amplified in the first round PCR using HB8F and HB6R primers. A second round of PCR using 11 sets of oligonucleotides (HB1F-1R to HB12F-12R) was performed on the 3.2 $\mathrm{kb}$ fragment to produce 11 overlapping fragments that contributed to full genome sequence when aligned. Due to possibility of gaps, three alternate primer sets (HEP 13F-13R, HEP14F-14R and HEP15F-15R) were also used. All amplification reactions were carried out in a 96-well Thermal Cycler (Bio Rad, USA). The first round of PCR was undertaken for 35 cycles $\left(94^{\circ} \mathrm{C}\right.$ for 1 minute, $55^{\circ} \mathrm{C}$ for one minute and $72^{\circ} \mathrm{C}$ for 1.5 minutes) followed by an extension reaction at $72^{\circ} \mathrm{C}$ for five minutes. The second round PCR was performed for 30 cycles $\left(94^{\circ} \mathrm{C}\right.$ for one minute, $55^{\circ} \mathrm{C}$ for one minute and $72^{\circ} \mathrm{C}$ for one minute) followed by extension at $72^{\circ} \mathrm{C}$ for five minutes. The first roundPCR reaction liquidcontained 12.5 uL of 2x MiFi Mix, 1.0 uL of each oligonucleotides (10 uM), $5.5 \mathrm{uL}$ sterile $\mathrm{dH} 2 \mathrm{O}$ and $5 \mathrm{uL}$ of the extracted HBV DNA. The second round PCR reaction liquid contained the same reagent concentrations for each of the 11 sets of oligonucleotides, except that only $2 \mathrm{uL}$ of the first round PCR product was used as a template. Amplification with the three alternate prim- ers were performed at $94^{\circ} \mathrm{C}$ for 10 minutes followed by 40 cycles of $94^{\circ} \mathrm{C}$ for 45 seconds, $56^{\circ} \mathrm{C}$ for 45 seconds and $72^{\circ} \mathrm{C}$ for 45 seconds and a final extension of $72^{\circ} \mathrm{C}$ for 10 minutes. The reagent composition was the same as the first round PCR. A synthetic Hepatitis B virus isolate M1 (GenBank Accession number: GQ924603) was used as the positive control in the initial run to test the primers. A negative non-template control was also included in each run of the PCR.

\subsection{Post PCR Purification and Sequencing}

A 15uL aliquot of each PCR reaction was analyzed on 2\% agarose by gel electrophoresis and viewed under UV illumination. The agarosewas presented with Red Safe Dye (Intron Biotech, Korea) as an alternative to ethidiumbromide. The corresponding amplicons were extracted from the agarose gel and purified using Gel Extraction Kit (Qiagen, USA) according to the manufacturer's instruction. The final elution contained 35uL of purified PCR amplicons from which $5 \mathrm{uL}$ was reanalyzed on $2 \%$ agarose gel to confirm that the purification steps were performed precisely. All purified PCR amplicons were subjected to cycle sequencing using corresponding sense and antisense oligonucleotides prior to sequencing in 3730 Genetic Analyzer (Applied Biosystem, USA).

\subsection{Data Analysis}

The overlapping sense and antisense sequences, obtained by sequencing, were aligned to produce a full length genome of HBV using CLUSTAL Omega software (https://www.ebi.ac.uk/Tools/msa/clustalo/). The reference sequence used in the alignment was Hepatitis B virus isolate M1 (GenBank Accession number: GQ924603).The genotypes of Malaysian Hepatitis B carriers were determined by the Genotyper bioinformatics tool in the HEPSEQ: International Repository for Hepatitis B Virus Strain Data by the assembled genome sequences as an input (http:// www.hpabioinformatics.org.uk/HepSEQResearch/Public/ Tool/genotype_tool.php). Apart from that, phylogenetic trees were constructed to determine the genotypes and sub-genotypes of the full length sequences of Hepatitis B isolates using Mega 6.06, and neighbor joining method (bootstrap replication 1000x). Subsequently, the position of the $S$ gene region was identified and analyzed for the presence of variants. In addition, the obtained sequences were also analyzed at the basal core promoter (BCP), precore (PC), and core (C) region.

\section{Results}

\subsection{HBV Full Genome Amplification and Sequenc- ing}

Of the total 93 analyzed samples, 76 HBV complete nucleotide and 17 partial nucleotide sequences were obtained by PCR amplification and sequencing. The se 
Suppiah J et al.

Table 1. Demographic Data of Patients Participatingin the Study a

\begin{tabular}{lcc}
\hline & Group 1, Hbe Ag Positive $(\mathbf{n}=\mathbf{2 4})$ & Group 2, Hbe Ag negative $(\mathbf{n}=\mathbf{6 9})$ \\
\hline Age, $\mathbf{y}$ & $45.6 \pm 15.2$ & $50.5 \pm 15.8$ \\
Sex & & 43 \\
\hline Female & 14 & 26 \\
\hline Male & 10 & $1.510^{7} \pm 6.3 \times 10^{7}$ \\
HBV DNA copy, IU/mL & $5.2 \times 10^{7} \pm 1.3 \times 10^{8}$ & 91.3 \\
Normal ALT level, \% & 79.2 & 8.7 \\
Elevated ALT level, \% & 20.8 & $7(10.1)$ \\
No. HCC & $6(25.0)$ & $16(23.2)$ \\
Liver cirrhosis & $5(20.8)$ & $41(59.4)$ \\
Chronic Hepatitis B & $18(75)$ & $1(1.4)$ \\
Fulminant Hepatitis B & $0(0)$ & $2(2.9)$ \\
Acute Hepatitis B Flare & $1(4.1)$ & $2(2.9)$ \\
\hline Asymptomatic & $0(0)$ & \\
\hline
\end{tabular}

${ }^{\mathrm{a}}$ Data are presented as No. (\%) or Mean \pm SD.

Table 2. The Oligonucleotides Used in the Amplification of HBV Full Genome

\begin{tabular}{|c|c|c|}
\hline Oligonucleotide Identity & Sequence (5'-3') & Reference \\
\hline HB1F & AAGCTCTGCTAGATCCCAGAGT & Sugauchi et al.(2001) \\
\hline HB1R & GAAACATAGAGGTGCCTTGAGCAG & Sugauchi et al. (2001) \\
\hline HB2F & TGCTGCTATGCCTCATCTTC & Sugauchi et al. (2001) \\
\hline HB2R & CATACTTTCCAATCAATAGG & Sugauchi et al. (2001) \\
\hline HB3F & GCCAAGTCTGTACAACATCTTGAG & Sugauchi et al. (2001) \\
\hline HB3R & AGTTGGCGAGAAAGTGAAAGCCTG & Sugauchi et al. (2001) \\
\hline HB4F & CCTATTGATTGGAAAGTATGTCA & Sugauchi et al. (2001) \\
\hline HB4R & CGGGACGTAGACAAAGGACGT & Sugauchi et al. (2001) \\
\hline HB5F & CTCTGCCGATCCATACTGCGGAA & Sugauchi et al. (2001) \\
\hline HB5R & ТTAАССТААТСТССТСССССА & Sugauchi et al. (2001) \\
\hline HB6F & TTGTYTACGTCCCGTCGGCG & Sugauchi et al. (2001 \\
\hline HB6R & AACAGACCAATTTATGCCTA & Sugauchi et al. (2001) \\
\hline HB8F & TTCACСТCTGCCTAATCATC & Sugauchi et al.(2001 \\
\hline HB8R & ATAGGGGCATTTGGTGGTCT & Sugauchi et al.(2001) \\
\hline HB9F & TCAGGCAACTATTGTGGTTTCA & Sugauchi et al.(2001) \\
\hline HB9R & GGATAGAACCTAGCAGGCAT & Sugauchi et al. (2001) \\
\hline HB10F & CGCAGAAGATCTCAATCTCGG & Sugauchi et al. (2001) \\
\hline HB10R & GGGTTGAAGTCCCAATCTGGATT & Sugauchi et al. (2001) \\
\hline HB11F & GGGTCACCATATTCTTGGGAA & Sugauchi et al. (2001) \\
\hline HB11R & GAACTGGAGCCACCAGCAGG & Sugauchi et al. (2001) \\
\hline HB12F & GTGGAGCCCTCAGGCTCAGG & Sugauchi et al. (2001) \\
\hline HB12R & CGAGTCTAGACTCTGTGGTA & Sugauchi et al. (2001) \\
\hline HEP13F & GGACTCTTGGACTCTCAGCAA & Kahila Bar-Gal et al.(2012) \\
\hline HEP13R & GGCAGAGGTGAAAAAGTTGC & Kahila Bar-Gal et al.(2012) \\
\hline HEP14F & GCATAAATTGGTCTGTTCACCAG & Kahila Bar-Gal et al.(2012) \\
\hline HEP14R & CTCCACAGAAGCTCCAAATTC & Kahila Bar-Gal et al.(2012) \\
\hline HEP15F & GAATTTGGAGCTTCTGTGGAG & Kahila Bar-Gal et al.(2012) \\
\hline HEP15R & TCATCAАСТСАССССААСАСАG & Kahila Bar-Gal et al.(2012) \\
\hline
\end{tabular}


Figure 1. Phylogram Showing the Clustering of HBV Whole Genome Sequences According to Their Genotypes

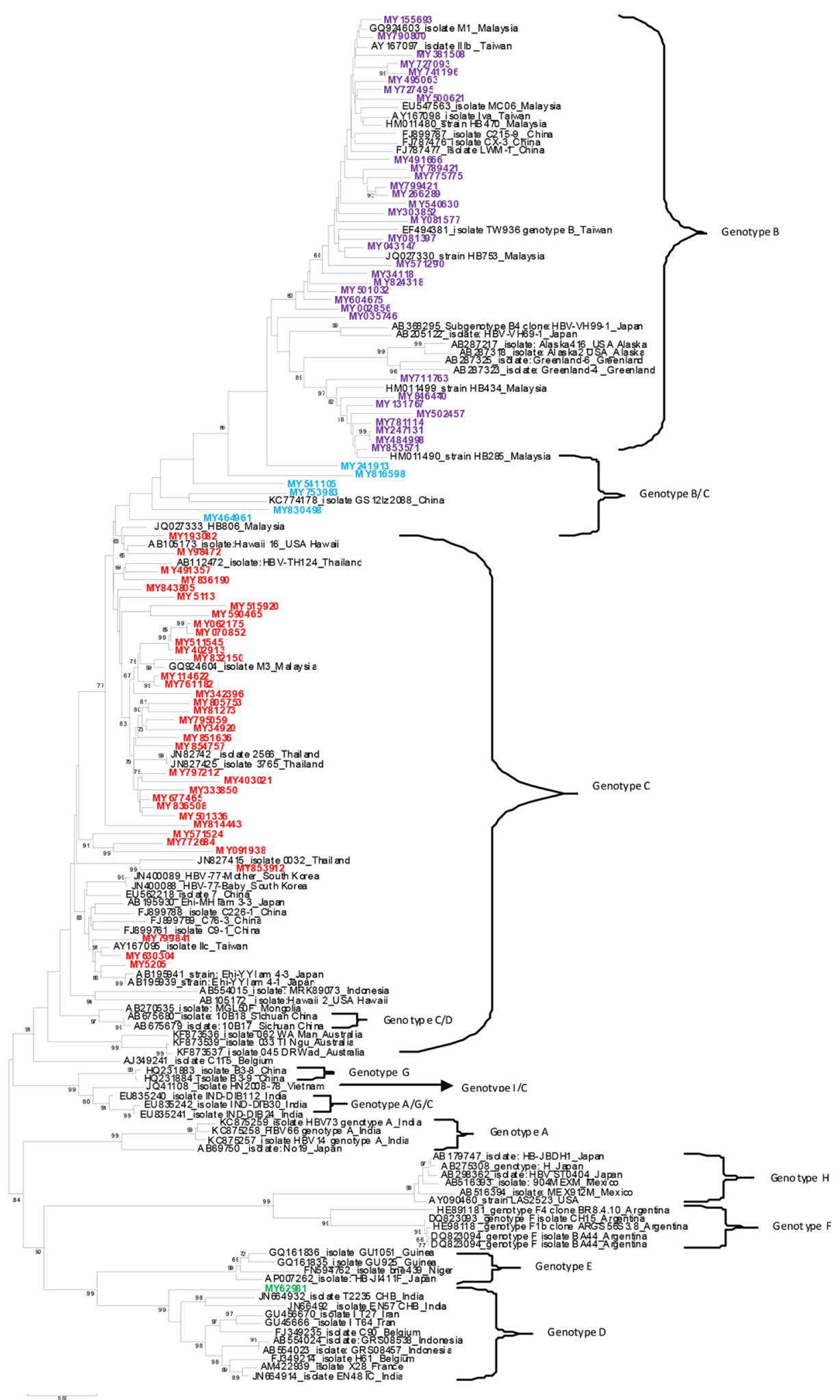

Malaysian HBV Isolates of the current Study Are Color Coded. 
quences were deposited into the GenBank (Accession numbers: KJ803752-KJ803827).Genotyping of the HBV full length and partial sequences based on the HEPSEQ software revealed a distribution of $49.46 \%, 48.39 \%$ and $2.15 \%$ of genotypes C,B, and D, respectively. The phylogenetic tree for 76 full-length isolates revealed similar clusters of genotypes with the exception of six sequences (MY830498, MY816598, MY753983, MY541105, MY241913 and MY464961) which fell into the $\mathrm{B} / \mathrm{C}$ recombinant cluster (Figure 1 ). The HEPSEQ software indicated that these sequences were genotype $\mathrm{C}$ with low probability, and therefore suggests possible recombinant strains. Jumping profile Hidden Markov Model (jpHMM) bioinformatics tool was utilized to confirm the presence of recombinant further. This software served as a tool to detect recombination in HIV-1 and hepatitis B virus (HBV) genomes (8). All six sequences were confirmed to be $\mathrm{B} / \mathrm{C}$ recombinant strain (Figure 2 ). The remaining 70 isolates were also analyzed and no re- combinant strains were found.

Phylogenetic analysis also demonstrated that Malaysian HBV isolates belonged to sub-genotypes B2 (78.79\%) and B3 (21.21\%) for genotype B, sub genotype D2 (100\%) for genotype D and sub geno type C1 (75.76\%), C2 (15.15\%), C3 (6.06\%) and C5 (3.13\%) for genotype C (Figure 3 - 5).

\subsection{S Gene Analysis}

The $S$ gene region in the whole genome of HBV was identified to be from 2848nucleotide (nt) to 3215nt and joined at position 1nt to 835nt. Two significant $S$ gene mutations were found in the Malaysian HBV sequences. The W182 stop codon (W182*) and deletion at open reading frame (ORF) of pre-S1 were present with the frequencies of $2.2 \%$ (2.93) and 5.4\% (5.93), respectively. There was no presence of MHR mutation in the $S$ gene region. The position of W182* and pre-S1 deletion were shown in Figure 6.

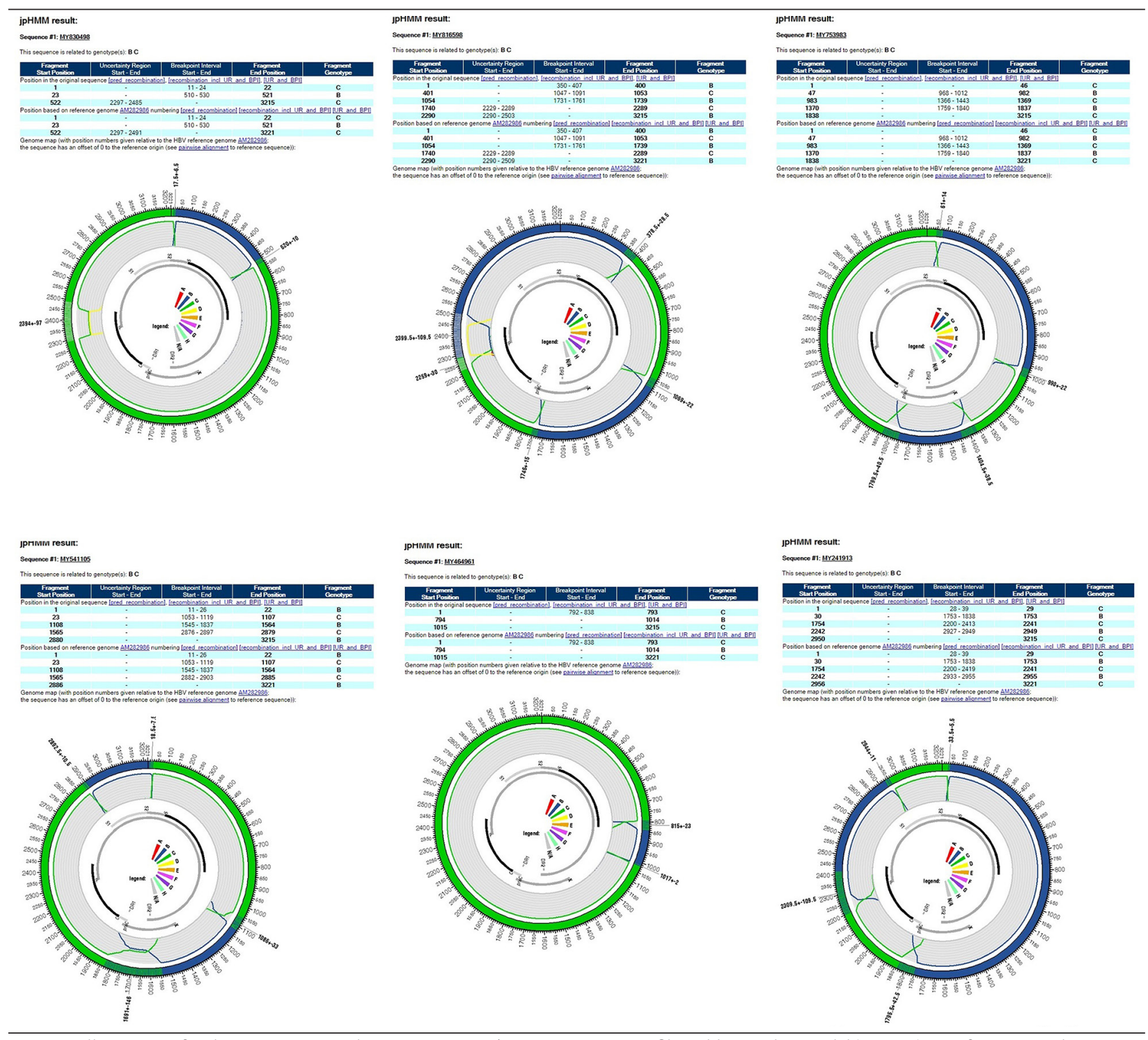

Figure 2. Illustration of Malaysian HBV Recombinant Genotype B/C Using Jumping Profile Hidden Markov Model (jpHMM) Bioinformatic Tool 


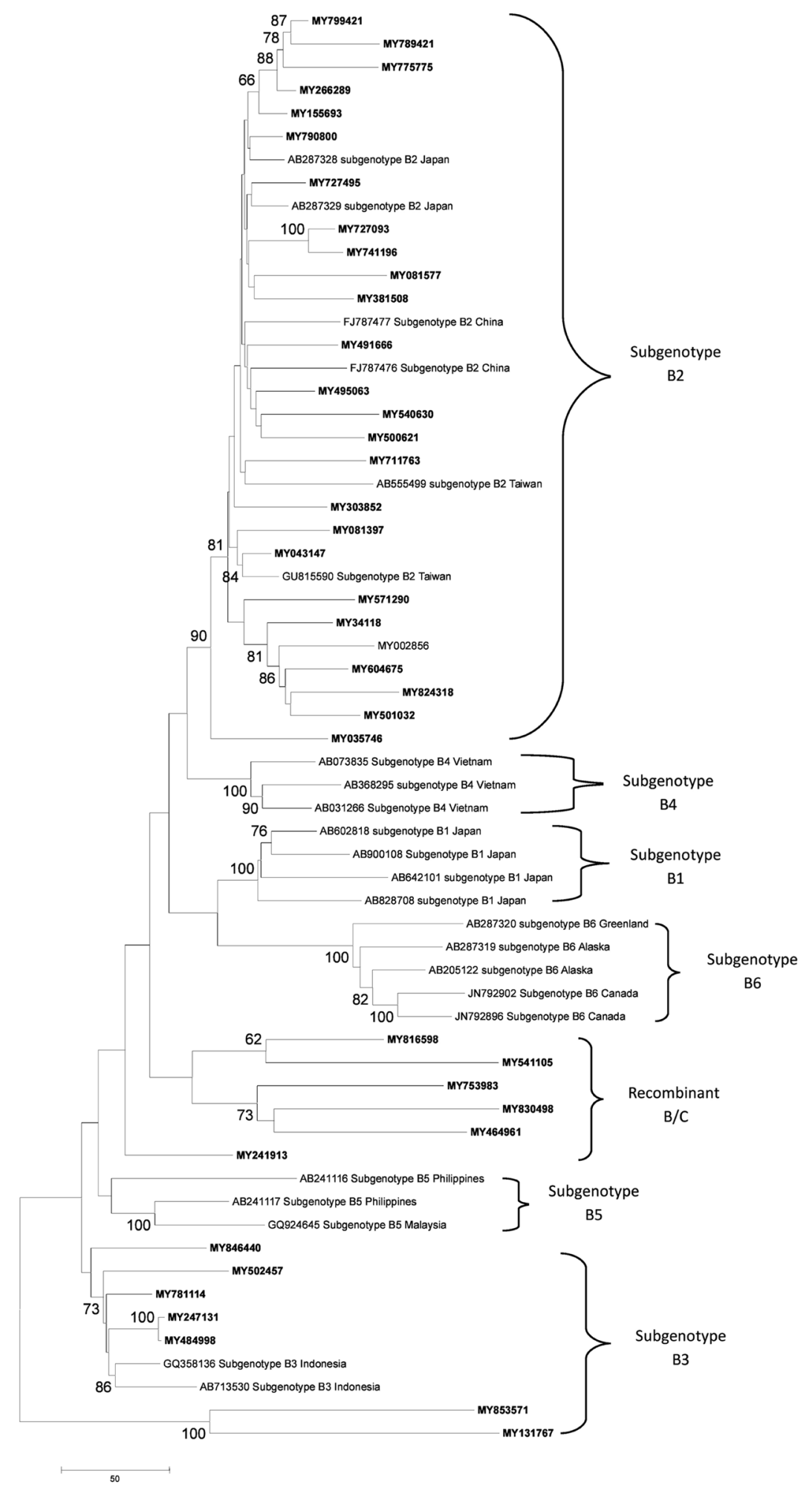

Figure 3. Phylogenetic Analysis to Group the HBV Sub-genotype B of the Malaysian HBV Isolates 


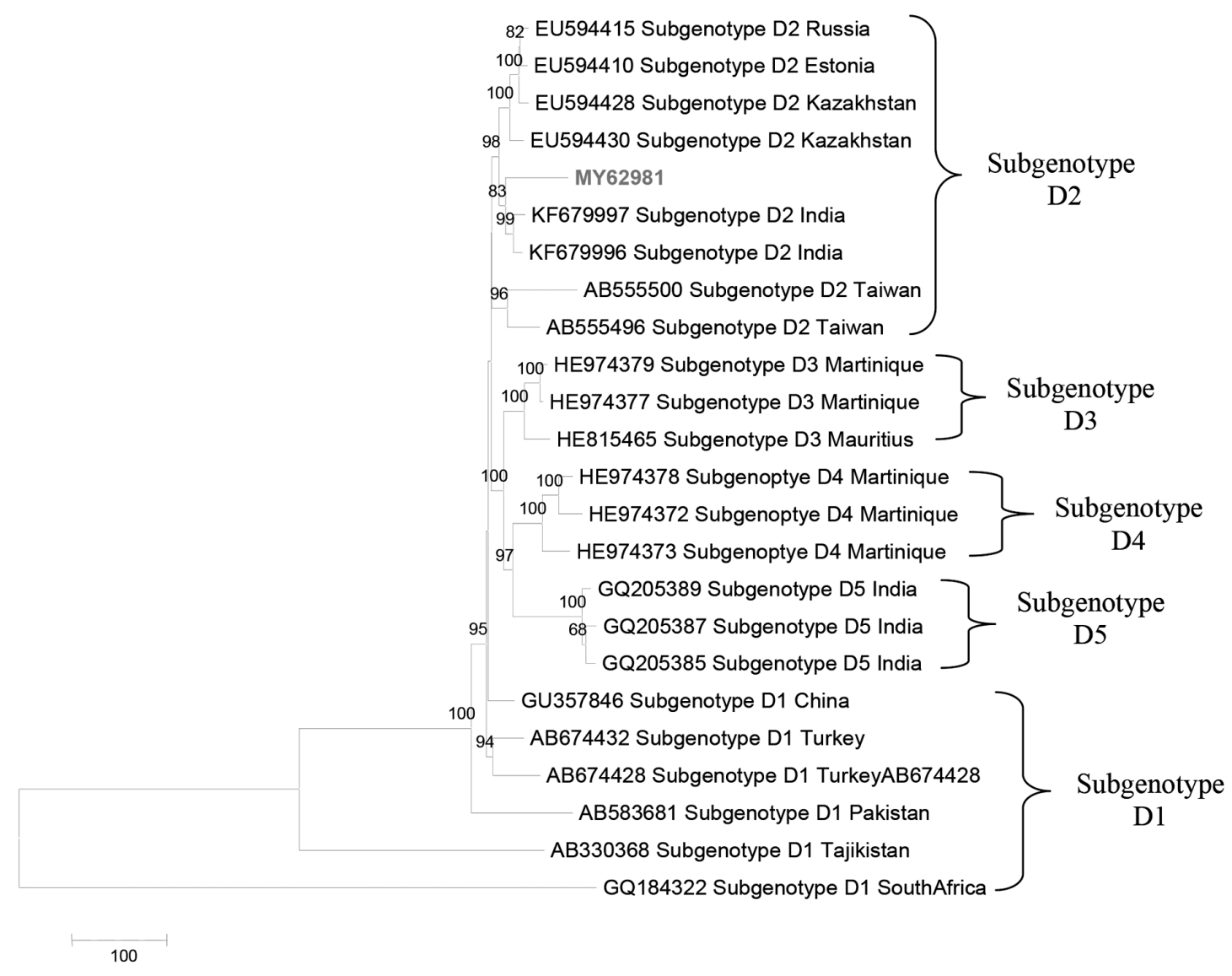

Figure 4. Phylogenetic Analysis to Group the HBV Sub-genotype D of the Malaysian HBV Isolate

\subsection{Case Report of W182 Stop Codon Mutation}

The characteristics of the two patients with W182* mutation were summarized in Table 3. Patients MY541105 and 062175 were both Malaysian Chinese, male, infected with HBV genotype C and diagnosed for chronic hepatitis B. Patient MY541105 didnot receive treatment and was not followed up due to transportation issues. Patient 062175 was given entecavir for a month in 2012. Liver CT revealed large hepatocellular carcinoma (HCC) in the right lobe of the liver and within four months, progression of the disease was observed as the huge HCC was complicated with bleeding and the presence of regenerate nodule in segment three of the liver. Patient has had no recent visits to the hospital.

\subsection{Case Report of ORF Deletion in Pre-S1}

Five patients (MY630304, MY62981, MY853571, MY851636 and MY131767) possessed nucleotide deletions at the ORF of pre-S1 region of HBV. The number of nt deletions in this region varied in all five patients; MY630304, MY62981, MY853571 and MY851636, and MY131767demonstrated 21, 33, 12, and 17 nt deletions, respectively. All patients were female except one, with the age ranging from 27 to 47 years. Details of the patients were indicated in Table 4. Patient MY630304 was a male diagnosed with liver cirrhosis, secondary to chronic positive hepatitis B e Antigen (HBeAg +ve). The patient was initially treated with lamivudine before switching to tenofovir due to viral suppression failure. The HBV whole genome analysis of this patient also showed the presence of lamivudine resistant mutation in the P gene reported in the authors ' previous publication (9). Patient MY853571 was a female diagnosed with chronic hepatitis $\mathrm{B}$. The patient was treated with lamivudine for a period of two years (2009-2011). Patient MY62981 was also a female diagnosed with chronic hepatitis B. The patient had a family history of hepatitis B and HCC among two of the four siblings as well as the husband. Patient MY851636 was a female referred to the hospital for acute hepatitis $B$ flare. The patient had presented jaundice, fatty liver, and intrahepatic cholestasis in pregnancy. Patient's brother had passed away because of ascites when 38 years old. Patient MY131767 had chronic HBeAg negative, diagnosed since 2003 during blood donation. This patient did not have hepatitis B family history. 


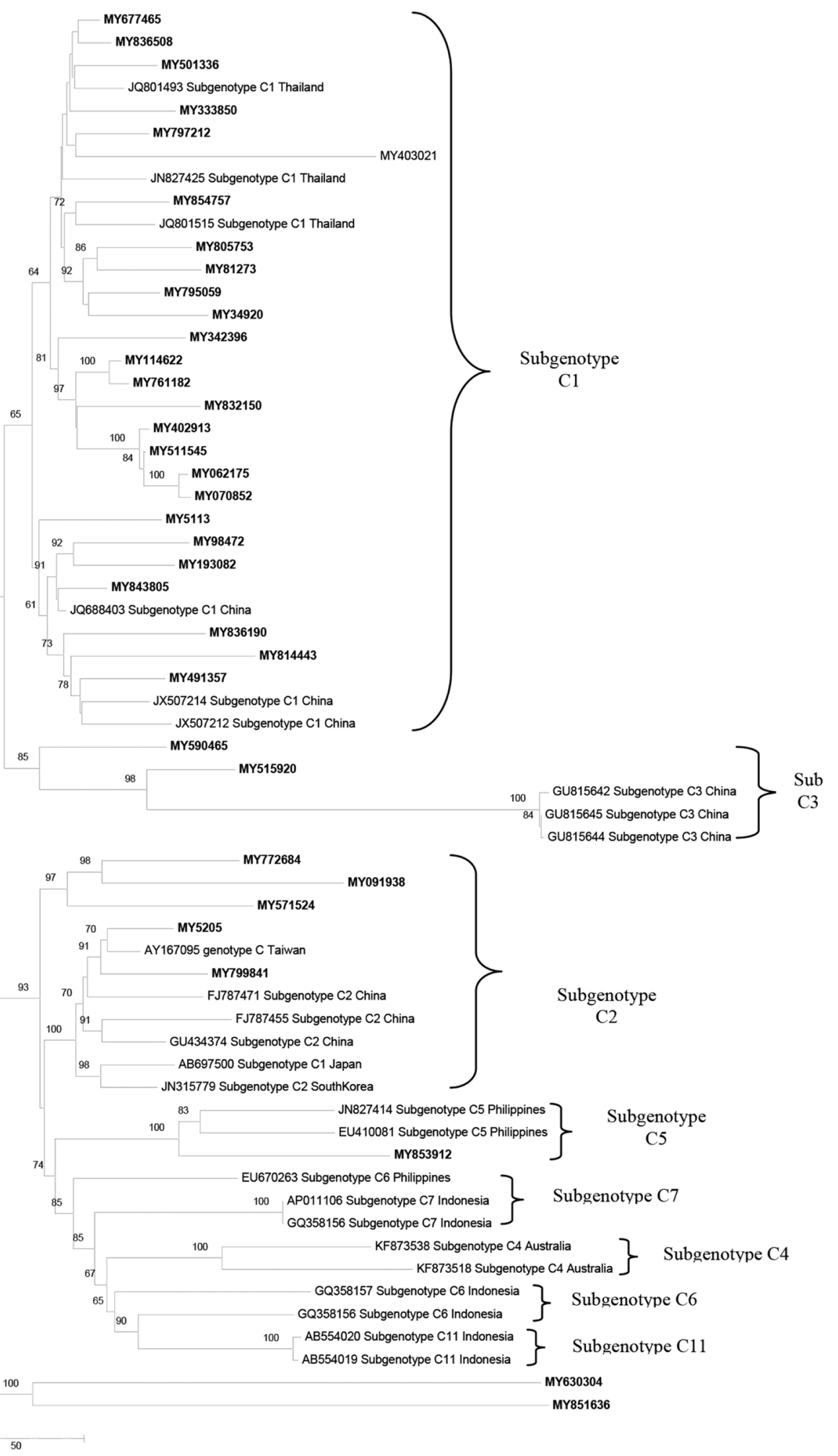

Figure 5. Phylogenetic Analysis to Group the HBV Sub-genotype C of the Malaysian HBV Isolates 
A) CLUSTAL O(1.2.1) multiple sequence alignment

\begin{tabular}{|c|c|}
\hline MY 62981 & MG- \\
\hline GQ924603 & RKGMGTNLSVPNPLGFFPDHQLDPAFKANSENPDWDLNPHKDNWP \\
\hline MY853571 & - -SKPRQGMGTNLSVPNPLGFFPDHQLDPAFKANSDNPD \\
\hline MY131767 & - -KPRQGMGTNLSVPNPLGFFPDHQLDPAFKANSDNPDWDLNPHKDNWP \\
\hline MY630304 & - RQGMGTNLSVPNPLGFFPDHQLDPAFGANSNNPDWDFNPNKDHWP \\
\hline MY851636 & 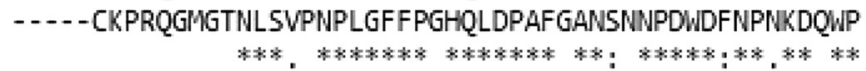 \\
\hline
\end{tabular}

B) CLUSTAL O(1.2.1) multiple sequence alignment

$\begin{array}{ll}\text { MY541105 } & \text { FSWLSLLVPFVQ*FVGLSPTWLSVIWMWVWGPSLYNI } \\ \text { MY962175 } & \text { FSWLSLLVPFVQ*FVGLSPTWLSVIWMWWWGPSLYNI } \\ \text { GQ924603 } & \text { FSWLSLLVPFVQWFVGLSPTWLSVIWMWWFGPSLYNI } \\ \text { MY741196 } & \text { FSWLSLLVPFVOWFVGSPTWLSVIWMWFWGPSLYNI } \\ \text { MY832150 } & \text { FSWLSLLVPFVQWFVGSPTWLSVIWMWWWGPSLYNI } \\ & * * * * * * * * * * * * * * * * * * * * * * * * * * * * * * * * * * *\end{array}$

Figure 6. A) Deletion at ORF of Pre S1 region of the HBV genome in five patients Comparison was made with the reference sequence GQ924603 by alignment in Clustal Omega tool; B) W182 stop codon in the S gene region of HBV in two patients. A substitution of TGG-TGA at nucleotide position 700 in hepatitis B full genome contributed to the stop codon (opal). Comparison was made with reference sequence (GQ924603) and wild type patients.

\begin{tabular}{|c|c|c|c|c|c|c|c|}
\hline Patient ID & Sex & Age & $\begin{array}{c}\text { History of } \\
\text { Treatment }\end{array}$ & HBV VIRAL LOAD & $\begin{array}{c}\text { HBV } \\
\text { Genotype }\end{array}$ & $\begin{array}{l}\text { HBsAg } \\
\text { Status }\end{array}$ & Clinical Diagnosis \\
\hline MY541105 & M & 24 & $\begin{array}{l}\text { No treatment } \\
\text { recorded }\end{array}$ & NA & $\mathrm{C}$ & Positive & -Chronic Hepatitis B; Mild neutropenia \\
\hline MY062175 & M & 46 & $\begin{array}{l}\text { Given entecavir } \\
\text { in April 2012, } \\
\text { prescribe for } 1 \\
\text { month only }\end{array}$ & $\begin{array}{l}\text {-Initial count in } \\
\text { April 2012:1.2 × } 10^{6} \\
\text { IU/mL; In April } \\
\text { 2013:236 IU/mL }\end{array}$ & $\mathrm{C}$ & Positive & $\begin{array}{c}\text {-Chronic Hepatitis B; Known Hepatitis B diagnosed } \\
\text { at age 23yrers-HBsAg +ve; -HBeAg+ve; -Hepatocel- } \\
\text { lular CA showed large HCC in right lobe that pro- } \\
\text { gressed to bleeding; -Some fluid around tumor }\end{array}$ \\
\hline
\end{tabular}

a Abbreviations: ID = Identification, HBV = Hepatitis B Virus, HBsAg = Hepatitis B surface antigen.

\begin{tabular}{|c|c|c|c|}
\hline Patient ID & Sex & Age & History oF Treatment \\
\hline MY630304 & M & 46 & $\begin{array}{l}\text {-Initially on Lamivu- } \\
\text { dine since June; } 2009 \text {, } \\
\text { later switched to teno- } \\
\text { fovir from July } 2011 \text { till } \\
\text { May } 2012 \text { due to failure } \\
\text { of viral suppression }\end{array}$ \\
\hline
\end{tabular}

\begin{tabular}{|c|c|c|c|c|c|c|}
\hline MY62981 & $\mathrm{F}$ & 47 & $\begin{array}{c}\text {-On lamivudine from } \\
\text { 2009-2011 }\end{array}$ & $\begin{array}{l}\text { In April 2011: < 6.0 IU/mL } \\
\text { In April 2012: 7663IU/mL In } \\
\text { June2013: 5896IU/mL }\end{array}$ & $\mathrm{D}$ & Positive \\
\hline MY853571 & $\mathrm{F}$ & 27 & No treatment recorded & In September 2013: $9.9 \times 10^{7} \mathrm{IU} /$ & $\mathrm{B}$ & positive \\
\hline
\end{tabular}
$\mathrm{mL}$

\begin{tabular}{ccc}
$\begin{array}{c}\text { HBV } \\
\text { Genotype }\end{array}$ & $\begin{array}{c}\text { HbsAg; } \\
\text { Status }\end{array}$ & Clinical Diagnosis \\
\hline C & positive & $\begin{array}{c}\text {-Liver cirrhosis secondary } \\
\text { to Chronic Hepatitis B; } \\
\text {-HBeAg+ve; -Pt keeping; well } \\
\text { and no signs of liver decom- } \\
\text { pensation after receiving; } \\
\end{array}$ \\
& & tenofovir
\end{tabular}

-Chronic Hepatitis B; -HBeAg negative; -No cirrhosis;-SG Abdomen showed liver diffusely increased in echogenecity, no focal lesion, normal in size, no ascites; - Fatty liver

Chronic Hepatitis B; HBeAg +ve; Has family history of HCC and Hep B; Husband too has Hep B; US Abdomen showed normal hepatobiliary system and tiny non obstructive calculus in left lower pole 
Suppiah J et al.

\begin{tabular}{|c|c|c|c|c|c|c|c|}
\hline MY851636 & $\mathrm{F}$ & 31 & No treatment recorded & NA & $\mathrm{C}$ & positive & $\begin{array}{l}\text {-Referred for acute Hep B } \\
\text { flare; -No liver decompensa- } \\
\text { tion; Fatty liver in pregnancy; } \\
\text { Intrahepatic Cholestatic in } \\
\text { pregnancy; Jaundice; Family } \\
\text { history: Brother had ascites } \\
\text { and passed away }\end{array}$ \\
\hline MY131767 & $\mathrm{F}$ & 34 & No treatment recorded & $\begin{array}{l}\text { Nov 2010: } 14291 \mathrm{IU} / \mathrm{mL} \text { July } \\
\text { 2012: } 32460 \mathrm{IU} / \mathrm{mL} \text { March 2013: } \\
\text { 44172IU/mL }\end{array}$ & B & positive & $\begin{array}{c}\text {-Chronic Hepatitis B; HBeAg } \\
\text { negative; No family history } \\
\text { of Hep B/ HCC; -No liver cir- } \\
\text { rhosis }\end{array}$ \\
\hline
\end{tabular}

a abbreviations: ID = Identification, HBV = Hepatitis B Virus, HBsAg = Hepatitis B surface antigen.

\begin{tabular}{lc}
\hline Table 5. BCP, CP and Core Region Mutations and Prevalence of Occurrence in thePresent Study $\mathrm{a}, \mathrm{b}$ \\
\hline C Gene Mutations & Prevalence of Occurrence \\
\hline C1653 T & 8.6 \\
A1752 G & 10.8 \\
1762 AGG-TGA 1764 & 26.9 \\
C1766 T & 2.2 \\
T1768 A & 10.8 \\
C1858 T & 64.5 \\
\hline G1896 A & 25.8 \\
\hline
\end{tabular}

a Data are presented as \%.

b Basal Core Promoter and Core Promoter Mutations and Prevalence of Occurrence in the Present Study.

\subsection{BCP, PC and C Region Analysis}

Analysis of all sequences with complete $C$ gene region showed the presence of several important mutations (Table 5). The most common mutation observed was precore mutation C1858 T which comprised $64.5 \%$ of the sequencedisolates. Another identified precore mutation was G1896A with the occurrence of $25.8 \%$. Among the basal core promoter mutations, A1762T-G1764A double mutation was present in $26.9 \%$, C1653T in $8.6 \%$, A1752G in $10.8 \%$ and $\mathrm{C} 1766 \mathrm{~T}$ in $2.2 \%$ of the isolates.

\section{Discussion}

In the current study two significant mutations were identified in the $S$ gene of HBV isolated from Malaysian hepatitis B carriers. The most common mutation in the $S$ region was the pre-S1 deletion which leads to an inefficient immune response $(10,11)$. The occurrence of pre-S1 deletion in the current study population was significantly more prevalent in the female patients $(4.5 ; 80 \%)$. This result was different from that of another study which demonstrated that pre S deletions (pre-S1 and pre-S2) were detected in a higher frequency in male (12). No clear association with genotype was found in this study. However, evidence that preS1 deletion is inherent in genotype D may support the current study findings whereby one of the five patients with pre S1 deletion was infected with HBV genotype $\mathrm{D}(13,14)$. In addition, the length of the pre S1 deletion (33 nt) in the genotype $\mathrm{D}$ patient was longer than those of the other genotypes. This finding was similar to several studies which reported that genotype D of HBV has the characteristic of $33 \mathrm{nt}$ deletion (15-17). The present study demonstrated that pre-S1 deletion mutants of HBV occurred in $80 \%$ (4.5) of the individuals with chronic hepatitis B infection. Only one was diagnosed with acute Hepatitis B. There was a similar finding that underscored the emergence of pre-S mutations in the chronic infections (17). The pre-S regions play an essential role in the interaction with the immune responses because they contain several epitopes for T or B cells, therefore deletion in this region seems to represent desperate escape of HBV from the host immune surveillance. Many studies have reported the association of pre-S1 deletion with HCC and progressive liver disease $(12,18,19)$. There was no such association in the current study. In contrast, a study showed that pre-S1 deletion was common in asymptomatic HBV carriers (ASC) (14). A reported meta-analysis study indicated that the frequency of pre-S1 deletion consecutively increased during progression of chronic hepatitis B from ASC states to liver cirrhosis (LC) or HCC (13). Therefore asymptomatic chronic HBV carriers with early detection of pre-S1 deletion should not be neglected and need to be included in the surveillance programs for HCC. of the five patients with HBV pre-S1 deletion had a family history of hepatitis B suggesting that the variation might be inherited. However there was little evidence supporting that preS1 deletion was transmissible. The occurrence of another mutation W182* was identified in the present study in two HBV patients. This mutation is known to cause a premature termination in the pre-S1 region which subsequently 
prevents the expression of $S$ gene full length. Association of HBV genotypes and occurrence of W182* mutant is not clearly known. The current study findings revealed that both patients with this mutation were infected with HBV genotype $C$ suggesting the probable association of genotype $\mathrm{C}$ and presence of W182* mutant. One of the patients showed progression of liver disease to HCC complicated with bleeding within a few months. The other patient could not be followed up, thus the current status is unknown. This crucial finding suggests that W182* could serve as a molecular marker to predict HCC. Other studies have also reported that the presence of W182* mutation in patients with Hepatitis Bcaused progressive forms of the disease (HCC and liver disease) $(20,21)$. Hepatitis B virus can evolve by mutations in the major hydrophilic region (MHR) of the HBsAg which allows its escape from host immune responses (22). The MHR region contains residues 99-169 of HBsAg and T/I126S, Q129H, G130N, S143L, D144A, G145A, and G145R were among the commonly reported mutations. However none of these mutations were detected in the current study. In conclusion, genomic analysis of the of HBV S gene isolated from Malaysian HBV carriers revealed the occurrence of two important variants,pre-S1 deletion and W182* mutant. The pre-S1 deletion was highly prevalent in female with chronic hepatitis B and with family history of hepatitis B. The W182* mutant was present in HBV genotype $\mathrm{C}$ and patients who showed progression to HCC. These findings will add more information to the current database of the clinically significant mutations in Malaysian Hepatitis B isolates. It would be interesting to conduct continuous surveillance among Malaysian hepatitis B carriers for the presence of these mutations along with other $\mathrm{S}$ gene mutations to establish probable association with genotypes, clinical symptoms or progression of hepatitis infection.

\section{Acknowledgements}

The authors would like to thank the Director General of Health Malaysia for his permission to publish this paper. The authors also would like to extend their gratitude to Dr. Shahnaz Murad, The Deputy Director of Research and Technical Support of Ministry of Health Malaysia for her support. This project was funded by the Ministry of Health Malaysia (JPP-IMR: 12-006, NMRR-12-311-11789 and Akaun Amanah 16833). Authors acknowledge the use of the HepSEQ-Hepatitis B resource (www.hpeseqresearch. org). Gnaneshan S., Ijaz S., Moran J., Ramsay M. and Green J. (2007) HepSEQ: International Public Health Repository for Hepatitis B. Nucleic Acids Res., 35 (Database Issue): D367-70.

\section{Authors' Contributions}

Jeyanthi Suppiah was involved in the entire study, conducting experiments, analysis and interpretation of data and drafting the manuscript. Rozainanee Mohd Zain delivered intellectual content to the study. Salbiah Haji
Nawi and Norazlah Bahari contributed to sample provision and clinical knowledge. Zainah Saat contributed to intellectual content, study design, concept and revision of the manuscript.

\section{Funding/Support}

This study was funded by Ministry of Health, Malaysia (JPP-IMR: 12-006, NMRR-12-311-11789 and Akaun Amanah16833).

\section{References}

1. Coleman PF. Detecting hepatitis B surface antigen mutants. Emerg Infect Dis. 2006;12(2):198-203.

2. Quer J, Martell M, Rodriguez FA, Bosch A, Jardi R, Buti M, et al. The Impact of Rapid Evolution of Hepatitis Viruses.: Academic Press; 2008.

3. Yousuf R, Rapiaah M, Ahmed SA, Rosline H, Salam A, Selamah S, et al. Trends in hepatitis B virus infection among blood donors in Kelantan, Malaysia: a retrospective study. Southeast Asian JTrop Med Public Health. 2007;38(6):1070-4.

4. Merican I, Guan R, Amarapuka D, Alexander M, Chutaputti A, Chien R, et al. Chronic hepatitis B virus infection in Asian countries. Journal of Gastroenterology and Hepatology. 2000;15(12):135661.

5. Pourkarim MR, Amini-Bavil-Olyaee S, Kurbanov F, Van Ranst M, Tacke F. Molecular identification of hepatitis B virus genotypes/ subgenotypes: revised classification hurdles and updated resolutions. World J Gastroenterol. 2014;20(23):7152-68.

6. Sugauchi F, Mizokami M, Orito E, Ohno T, Kato H, Suzuki S, et al. A novel variant genotype $C$ of hepatitis $B$ virus identified in isolates from Australian Aborigines: complete genome sequence and phylogenetic relatedness. J Gen Virol. 2001;82(Pt 4):883-92.

7. Kahila Bar-Gal G, Kim MJ, Klein A, Shin DH, Oh CS, Kim JW, et al. Tracing hepatitis B virus to the 16th century in a Korean mummy. Hepatology. 2012;56(5):1671-80.

8. Schultz AK, Bulla I, Abdou-Chekaraou M, Gordien E, Morgenstern B, Zoaulim F, et al. jpHMM: recombination analysis in viruses with circular genomes such as the hepatitis B virus. Nucleic Acids Res. 2012;40(Web Server issue):W193-8.

9. Suppiah J, Mohd Zain R, Haji Nawi S, Bahari N, Saat Z. Drug-resistance associated mutations in polymerase (p) gene of hepatitis B virus isolated from malaysian HBV carriers. Hepat Mon. 2014;14(1).

10. Liu S, Zhang H, Gu C, Yin J, He Y, Xie J, et al. Associations between hepatitis $B$ virus mutations and the risk of hepatocellular carcinoma: a meta-analysis. J Natl Cancer Inst. 2009;101(15):1066-82.

11. Weinberger KM, Zoulek G, Bauer T, Bohm S, Jilg W. A novel deletion mutant of hepatitis B virus surface antigen. J Med Virol. 1999;58(2):105-10.

12. Yeung P, Wong DK, Lai CL, Fung J, Seto WK, Yuen MF. Association of hepatitis B virus pre-S deletions with the development of hepatocellular carcinoma in chronic hepatitis B. J Infect Dis. 2011;203(5):646-54.

13. Cao GW. Clinical relevance and public health significance of hepatitis B virus genomic variations. World J Gastroenterol. 2009;15(46):5761-9.

14. Biswas A, Panigrahi R, Banerjee A, Pal M, De BK, Chakrabarti S, et al. Differential pattern of pre-S mutations/deletions and its association with hepatitis B virus genotypes in Eastern India. Infect Genet Evol. 2012;12(2):384-91.

15. Sengupta S, Panda SK, Acharya SK, Durgapal H. Role of hepatitis B virus genotype D \& its mutants in occult hepatitis B infection. Indian J Med Res. 2013;138(3):329-39.

16. Schaefer S. Hepatitis B virus: significance of genotypes. J Viral Hepat. 2005;12(2):111-24.

17. Kay A, Zoulim F. Hepatitis B virus genetic variability and evolution. Virus Res. 2007;127(2):164-76.

18. Chen $\mathrm{CH}$, Hung $\mathrm{CH}$, Lee CM, Hu TH, Wang JH, Wang JC, et al. Pre-S 
deletion and complex mutations of hepatitis B virus related to advanced liver disease in HBeAg-negative patients. Gastroenterology. 2007;133(5):1466-74.

19. Chen BF, Liu CJ, Jow GM, Chen PJ, Kao JH, Chen DS. High prevalence and mapping of pre-S deletion in hepatitis B virus carriers with progressive liver diseases. Gastroenterology. 2006;130(4):1153-68.

20. Lee SA, Kim K, Kim H, Kim BJ. Nucleotide change of codon 182 in the surface gene of hepatitis $B$ virus genotype $C$ leading to trun- cated surface protein is associated with progression of liver diseases. J Hepatol. 2012;56(1):63-9.

21. Kim BJ. Hepatitis B virus mutations related to liver disease progression of Korean patients. World $J$ Gastroenterol. 2014;20(2):460-7.

22. Shi Y, Wei F, Hu D, Li Q, Smith D, Li N, et al. Mutations in the major hydrophilic region (MHR) of hepatitis B virus genotype $C$ in North China. J Med Virol. 2012;84(12):1901-6. 